\title{
Ecophysiological adaptation strategies of some intertidal marine macroalgae of the Israeli Mediterranean coast
}

\author{
Rachel Einav ${ }^{1}$, Siegmar Breckle ${ }^{2}$, Sven Beer ${ }^{1, *}$ \\ 'Department of Botany, Tel Aviv University, Tel Aviv 69978, Israel \\ ${ }^{2}$ Department of Ecology, The Faculty of Biology, Bielefeld University, PO Box 100131, D-33501 Bielefeld, Germany
}

\begin{abstract}
The dominant macroalgae growing at a rocky site on the lsraeli coast were examined for ecophysiological responses to varying environmental parameters in an attempt to correlate such responses with their appearance at distinct vertical heights within the intertidal zone. These responses were measured as the photosynthetic performance during various conditions of light, temperature, salinity, inorganic carbon and desiccation and were compared with algae cover during the year. While all algae apparently grew under light-saturating conditions, Enteromorpha compressa and Ulva lactuca, which occupy the uppermost level of the zone, were very tolerant to high and low temperatures as well as desiccation and varying salinity levels. They were also saturated both by $\mathrm{HCO}_{3}^{-}$(while submerged) and atmospheric $\mathrm{CO}_{2}$ (during emergence). In contrast, 4 of the species dominating the middle and lower parts of the intertidal showed a narrower temperature response, could not tolerate exposure to high temperatures for prolonged time periods and were more sensitive to desiccation and salinity changes. In Acanthophora najadiformis and Hypnea musciformis, the sensitivity to desiccation in combination with the much higher rates of photosynthesis in air than in water might explain their growth in the mid intertidal, where, on one hand, waves would keep the thalli moist and, on the other hand, frequent exposure to air would ensure a high supply of atmospheric $\mathrm{CO}_{2}$. In all, these results show that the uppermost growing algae (Enteromorpha compressa and Ulva lactuca) are those that endure the most adverse atmospheric influences and thus can be assumed to lack competition from other species in the high intertidal. Even though they perform equally well under submerged conditions, it may be that biotic factors, such as grazing, limit them from growing lower down. In contrast, the other algae studied showed markedly adverse responses to atmospheric conditions, especially desiccation, and this may be what restricts them to the lower portion of the intertidal.
\end{abstract}

KEY WORDS: Algae - Intertidal · Ecophysiology · Desiccation $\cdot$ Photosynthesis

\section{INTRODUCTION}

The intertidal comprises habitats in which algae grow under varying conditions, from almost total submersion to high above the average tide level. These habitats are characterised not only by their vertical height and, thus, degree of air exposure, but also by degree of waves and spray, as well as varying temperatures and humidity. It has classically been thought that the response of marine algae to air exposure is

- Addressee for correspondence;

E-mail: svenbeer@ccsg.tav.ac.il negative (cf. Dring 1994) and that those plants which survive in the intertidal zone carry a high degree of resistance to adverse atmospheric conditions such as desiccation (Schonbeck \& Norton 1979, Oates 1985), overheating (Smith et al. 1986) and salinity (Kirst 1990).

Intertidal rocky habitats often show a high diversity, as well as density, of algae, and it is therefore reasonable to assume that some algae can benefit from air exposure by receiving more light and different temperatures and that ' $\mathrm{CO}_{2}$ users' may be able to acquire inorganic carbon from the atmosphere more easily 
than from the seawater (Madsen \& Maberly 1990, Surif \& Raven 1990, Einav \& Beer 1993). Air contains about $16 \mu \mathrm{M} \mathrm{CO}_{2}(350 \mathrm{ppm})$ which, in seawater, is in equilibrium with a concentration of ca $10 \mu \mathrm{M}$ (depending on temperature) dissolved $\mathrm{CO}_{2}$. Since the diffusivity of $\mathrm{CO}_{2}$ in water is orders of magnitude lower than in air, and since uncatalysed dehydration rates of $\mathrm{HCO}_{3}{ }^{-}$to form $\mathrm{CO}_{2}$ are low, plants living in seawater would be restricted to $\mathrm{CO}_{2}$ as their only source of inorganic carbon available for utilisation. Under such conditions, many marine algae have been found able to utilise the much higher concentration of $\mathrm{HCO}_{3}{ }^{-}$(Reiskind et al. 1989, Johnston 1991, Beer 1994).

The 6 most common algae growing along the Mediterranean rocky shore of Israel during the time of this study (1991-1992) were Enteromorpha compressa and Ulva lactuca (Chlorophyta), Acanthophora najadiformis and Hypnea musciformis (Rhodophyta), and Padina pavonia and Sargassum vulgare (Phaeophyta) These species were used here in a comparative study of physiological responses to varying ecological conditions within the intertidal. We measured photosynthetic rates of the algae during submersion or emergence as a function of light level, temperature, water content of the thalli and $\mathrm{HCO}_{3}{ }^{-}$as well as $\mathrm{CO}_{2}$ concentrations in order to evaluate their degree of adaptability to the conditions prevailing within the vertical zone in which they live. It is believed that such information may also be useful in estimating how they might adapt to coming environmental changes brought about by man (e.g. a doubling of the atmospheric and, hence, dissolved $\mathrm{CO}_{2}$ concentration within the decades to come).

\section{MATERIALS AND METHODS}

Field work was carried out at Zukai-Yam, located ca $3 \mathrm{~km}$ north of Netanya on the Mediterranean coast of Israel. The vertical range and percentage cover of the different species along $6 \mathrm{~m}$ transects were recorded monthly during a year. Plants were brought to the laboratory from June to October, where they were kept in natural, aerated seawater at $20^{\circ} \mathrm{C}$ in a normal day-night cycle, and experiments were performed within $3 \mathrm{~d}$ of collection.

Various abiotic conditions were simulated in the laboratory, and plant responses were usually measured on the net gas exchange level using infra-red gas analysis (IRGA) for emergent conditions and $\mathrm{O}_{2}$ electrode systems during submergence. When comparing submerged and emerged photosynthetic rates, the same $\mathrm{O}_{2}$ electrode system was used. Details of these methods have been described earlier (Einav \& Beer 1993).

Plant responses to irradiance were measured by exposing the algae to various irradiances (generated by a halogen lamp and neutral density filters) while measuring photosynthetic $\mathrm{O}_{2}$ evolution. A Lambda LiCor quantum sensor was used in order to measure the irradiance levels (in $\mu$ mol photons $\mathrm{m}^{-2} \mathrm{~s}^{-1}, \mathrm{PAR}$ ).

Temperature responses of the various algae were also measured in the $\mathrm{O}_{2}$ electrode systems. Initially, thalli were acclimated to $5^{\circ} \mathrm{C}$ for $30 \mathrm{~min}$, and the temperature was then slowly raised (in $5^{\circ} \mathrm{C}$ intervals for at least $20 \mathrm{~min}$ at each stable temperature). In other experiments, the temperature was raised to $37^{\circ} \mathrm{C}$ (the maximal natural temperature measured on emergent thalli in the summer) and the maximal time for which algae could retain positive net photosynthetic activity was measured.

Two different responses to desiccation were investigated. First, the photosynthetic response during exposure to air was measured using an open IRGA system (in differential mode). Plants were weighed before and after each experiment, and the dry weight was later determined at each instance of the photosynthetic time course (assuming exponentially decreasing water contents; see Beer \& Eshel 1983a for details). Second, the net photosynthetic performance upon recovery from various desiccation levels was measured using the $\mathrm{O}_{2}$ electrode. Plants were weighed and then left to desiccate to various water contents at room temperature $(20$ to $25^{\circ} \mathrm{C}$ ). The initial photosynthetic rate upon resubmersion was determined with the $\mathrm{O}_{2}$ electrodes at $25^{\circ} \mathrm{C}$ and $1000 \mu \mathrm{mol}$ photons $\mathrm{m}^{-2} \mathrm{~s}^{-1}$ for at least $15 \mathrm{~min}$. The various water contents at the end of the desiccation periods were calculated as (IW - DW)/(FW - DW) where IW is the thallus weight after a given period of desiccation, FW is the fresh weight and DW is the dry weight $\left(95^{\circ} \mathrm{C}\right.$ for $\left.24 \mathrm{~h}\right)$.

In order to measure salinity influences, and to differentiate between salinity effects per se and its effect on the plant water status, plants were immersed for $2 \mathrm{~h}$ in 5 different strengths $(0.75,1.0,1.5,2.0$ and 3.0$)$ of synthetic seawater [where the normal $(1.0)$ strength was composed of $0.5 \mathrm{M} \mathrm{NaCl}, 30 \mathrm{mM} \mathrm{MgSO}_{4}, 10 \mathrm{mM} \mathrm{KCl}$ and $10 \mathrm{mM} \mathrm{CaCl}_{2}$ ]. The solutions were enriched with $2.2 \mathrm{mM} \mathrm{NaHCO}_{3}$ as the inorganic carbon source. Algae were weighed (for $\mathrm{FW}$ ) and put into $\mathrm{O}_{2}$-electrode cells filled with the normal (1.0) solution to determine initial photosynthetic rates. Then these plants were immersed in $\mathrm{O}_{2}$-electrode cells filled with the various solutions and weighed again. By weighing the plants after additional time periods, it was established that a steadystate weight had been reached after $2 \mathrm{~h}$. Water content was calculated from the initial, final and dry weights as described for the desiccation experiments.

Photosynthetic responses of the algae to different conditions of inorganic carbon supply were measured in 4 different types of experiments. (1) For measuring responses to $\mathrm{CO}_{2}$ concentrations in the air, a closed IRGA system was used (with the instrument set to 
absolute mode). An initial concentration of $\mathrm{ca} 800 \mathrm{ppm}$ $\mathrm{CO}_{2}$ was applied, and the thalli then reduced this concentration within the closed system. It was ascertained that the thalli did not desiccate enough to alter photosynthetic rates during these experiments. (2) To determine inorganic carbon saturation points in seawater, photosynthesis was measured using the $\mathrm{O}_{2}$ electrodes. $\mathrm{NaHCO}_{3}$ was then added to the seawater in intervals until saturating rates had been reached. (3) In order to obtain a valid comparison between photosynthetic rates in air and in water, the $\mathrm{O}_{2}$ electrode system was used for both submerged and exposed plants. Details of this technique have been described before (Einav \& Beer 1993). (4) In order to distinguish between the use of $\mathrm{CO}_{2}$ and $\mathrm{HCO}_{3}{ }^{-}$during submergence, various ratios of the 2 inorganic carbon forms were obtained by varying the $\mathrm{pH}$ during photosynthetic measurements in the $\mathrm{O}_{2}$-electrode cell. Photosynthesis was thus measured at pH 8.2 (by adding $30 \mathrm{mM}$ Tris), pH 7.0 (by adding $30 \mathrm{mM}$ Hepes) or $\mathrm{pH} 5.6$ (by adding $30 \mathrm{mM}$ Mes). These buffers were added to the seawater medium after steady state photosynthetic rates had been reached, and the concentrations of $\mathrm{CO}_{2}$ and $\mathrm{HCO}_{3}{ }^{-}$at each $\mathrm{pH}$ were calculated as described by Beer \& Eshel (1983b).

All figures were plotted using SlideWrite 4.0, and data for the scatter-graphs were fitted to curves by second or third degree polynomial functions.

\section{RESULTS}

The vertical distributions of the investigated algae are shown in Table 1. The major parts of the Enteromorpha compressa and Ulva lactuca populations grow above the high tide mark. Hypnea musciformis and, especially, Acanthophora najadiformis appear within a narrow range of the mid-intertidal. Padina pavonia and Sargassum vulgare are mostly submerged plants, although Padina pavonia reaches the intertidal zone and is sometimes exposed. Table 1 also shows the proportional cover of each alga during the year within a typical transect. The algae chosen for this research represent the major species within the intertidal zone (except in December and January when Jania rubra is most abundant). Enteromorpha compressa and Ulva lactuca could be found during almost the whole year, but they are dominant from winter (January) until the middle of summer; later, the populations are destroyed as a result of storms or hot easterly winds. Recovery of the populations takes a few months.

In the laboratory, net photosynthetic rates of all the algae measured were light-saturated at PAR irradiances 10 to $20 \%$ of full sunlight (Fig. 1). Thus, it seems that there is no light limitation during most of the day within the intertidal zone.

The temperature responses of the algae differed mainly with respect to low temperatures, where Ulva lactuca and Enteromorpha compressa performed better then the others (Fig 2). All algae showed high photosynthetic rates at $37^{\circ} \mathrm{C}$ in short-term experiments, and we determined how long they could be photosynthetically active at this high temperature (Fig. 3). The red algae Acanthophora najadiformis and Hypnea musciformis could not photosynthesise for more than 15 minutes at $37^{\circ} \mathrm{C}$. This may prevent them from growing in higher, more air-exposed areas. On the other hand, the resistance of Ulva lactuca to high temperatures is remarkable in that it showed positive photosynthetic rates at $37^{\circ} \mathrm{C}$ for more than $3 \mathrm{~h}$.

Table 1. Percentage cover for each alga investigated during the months of a year and upper (UP) and lower (LO) borders of the algal populations in relation $(\mathrm{cm})$ to the mean tide. Where no data are given, algae were not present at that time

\begin{tabular}{|c|c|c|c|c|c|c|c|c|c|c|c|c|c|c|}
\hline & Aug & Sep & Oct & Nov & Dec & $\operatorname{Jan}$ & Feb & Mar & $\mathrm{Apr}$ & May & Jun & Jul & UP & LO \\
\hline $\begin{array}{c}\text { Enteromorpha } \\
\text { compressa }\end{array}$ & 16 & + & + & 3 & 4 & 18 & 88 & 84 & 88 & 73 & 62 & 70 & +70 & +10 \\
\hline $\begin{array}{l}\text { Ulva } \\
\text { lactuca }\end{array}$ & 4 & 2 & 8 & 4 & 3 & 10 & 9 & + & 2 & 2 & + & 6 & +50 & -30 \\
\hline $\begin{array}{c}\text { Acanthophora } \\
\text { najadiformis }\end{array}$ & 12 & 12 & 29 & 68 & 30 & 10 & & & & & 8 & 16 & +30 & -40 \\
\hline $\begin{array}{l}\text { Hypnea } \\
\text { musciformis }\end{array}$ & 10 & 60 & 29 & 4 & 2 & & & & 8 & 23 & 12 & 12 & +10 & -50 \\
\hline $\begin{array}{l}\text { Padina } \\
\text { pavonia }\end{array}$ & 29 & 21 & 30 & 7 & & & & & & & 4 & + & +20 & $<-100$ \\
\hline $\begin{array}{l}\text { Sargassum } \\
\text { vulgare }\end{array}$ & 20 & 2 & 3 & 4 & 4 & 10 & 2 & & 2 & 2 & 2 & 2 & -40 & $<-100$ \\
\hline $\begin{array}{l}\text { Others, mostly } \\
\text { Jania rubens }\end{array}$ & 9 & 3 & 1 & 10 & 43 & 52 & 1 & 16 & 10 & & 12 & & & \\
\hline
\end{tabular}



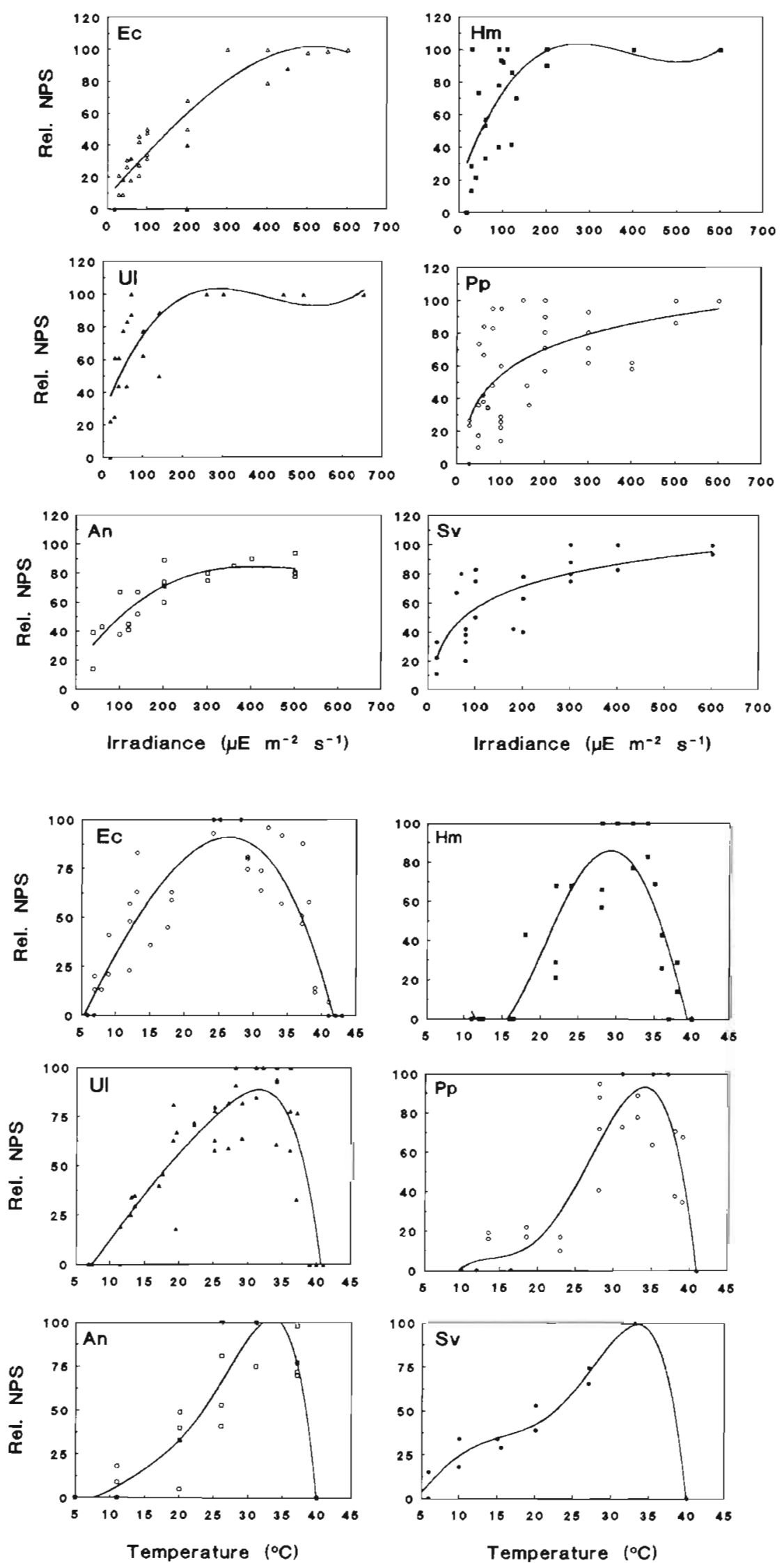

Fig. 1. Enteromorpha compressa (Ec), Ulva lactuca (Ul), Acanthophora najadiformis (An), Hypnea musciformis ( $\mathrm{Hm}$ ), Padina pavonia (Pp), and Sargassum vulgare (Sv). Net photosynthetic $\mathrm{O}_{2}$ evolution rates of submerged algae as a function of irradiance. Measurements were done on 5 thalli for each species at a temperature of $25^{\circ} \mathrm{C}$. Data are expressed relative to maximal rates obtained for each thallus. Average maximal rates (in $\mu \mathrm{mol}$ $\mathrm{O}_{2} \mathrm{~g} \mathrm{FW}^{-1} \mathrm{~h}^{-1} \pm \mathrm{SD}$ ) were (Ec) $331 \pm 53$; (UI) $249 \pm 45$; (An) $65 \pm 18$; (Hm) $41 \pm 14$;

(Pp) $61 \pm 16_{;}$(Sv) $31 \pm 14$

Fig 2. Enteromorpha compressa (Ec), Ulva lactuca (Ul), Acanthophora najadiformis (An), Hypnea musciformis $(\mathrm{Hm})$, Padina pavonia (Pp), and Sargassum vulgare (Sv). Net photosynthetic $\mathrm{O}_{2}$ evolution rates of submerged algae as a function of temperature. Measurements were done on 6 thalli of each species at an irradiance of 1000 $\mu \mathrm{mol}$ photons $\mathrm{m}^{-2} \mathrm{~s}^{-1}$ Data are expressed relative to maximal rates obtained for each thallus. Average maximal rates (in $\mu \mathrm{mol} \mathrm{O}_{2}$ $\mathrm{g} \mathrm{FW}^{-1} \mathrm{~h}^{-1} \pm \mathrm{SD}$ ) were $\left.\left(\mathrm{Ec} \mathrm{C}^{\circ}\right) 120 \pm 36_{i}(\mathrm{U})^{*}\right)$ $113 \pm 12_{i}(\mathrm{An} \cdot) 64 \pm 19 ;\left(\mathrm{Hm}^{*}\right) 77 \pm 22 i$ (Pp) $50 \pm 19$; (Sv) $20 \pm 9($ after Einav \& Beer 1993) 


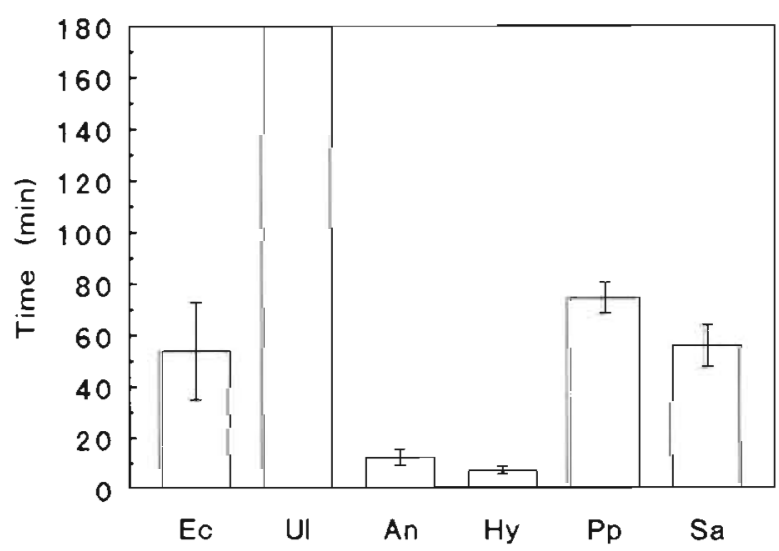

Fig. 3. Enteromorpha compressa (Ec), Ulva lactuca (Ul), Acanthophora najadiformis (An), Hypnea musciformis (Hm), Padina pavonia (Pp), and Sargassum vulgare (Sv). Maximal time during which algae could retain positive net photosynthetic activity in water at $37^{\circ} \mathrm{C}$. Measurements were done on 6 thalli of each species at an irradiance of $1000 \mu \mathrm{mol}$ photons $\mathrm{m}^{-2} \mathrm{~s}^{-1}$. Data are expressed relative to maximal rates obtained for each thallus. Ul $>3 \mathrm{~h}$

Fig. 4 shows the plants' ability to photosynthesise during exposure to air, and Fig. 5 the ability to recover after resubmergence following desiccation. These responses correlate with one another, as well as with the various species' vertical locations in the field, in that the high-growing species (especially Enteromorpha compressa) are much more resistant to desiccation than the others.

Salinity around and in the thalli increases while algae are exposed during low tide. This thus directly increases the ionic concentration, but it also reduces water potential (which is another way to cause desiccation). Fig. 6 shows the water content and photosynthetic rates after immersion in synthetic seawater of different salinities (see 'Materials and methods'). Some of the algae (Acanthophora najadiformis, Hypnea musciformis and Padina pavonia) were more sensitive to salinity than to desiccation. For example, at $70 \%$ thallus water content (resulting from a $3 \times$ seawater concentration), photosynthesis was zero while, during desiccation in air at the same water content, net photosynthesis was positive (Figs. $4 \& 5$ ). This indicates a direct effect of salinity which might occur if these plants were exposed.

Regarding the responses to external inorganic carbon, most algae showed close to saturated photosynthetic rates at atmospheric concentrations of $\mathrm{CO}_{2}$ during emergence (Fig. 7), and Enteromorpha compressa and UIva lactuca were saturated by inorganic carbon in seawater (Fig. 8). E. compressa, U. lactuca and Sargassum vulgare showed very similar photosynthetic rates in air and in water, but Padina pavonia, Hypnea musciformis and,
Fig. 4. Enteromorpha compressa (Ec), Ulva lactuca (Ul), Acanthophora najadiformis (An), Hypnea musciformis (Hm), Padina pavonia (Pp), and Sargassum vulgare (Sv). Net photosynthetic $\mathrm{CO}_{2}$ uptake rates of algae in air as a function of relative water content (during the course of desiccation). Measurements were done on 4 thalli for each species at a temperature of $25^{\circ} \mathrm{C}$. Data are expressed relative to maximal rates obtained for each thallus. Average maximal rates (in $\mu \mathrm{mol} \mathrm{CO}_{2}$ $\mathrm{g} \mathrm{FW}^{-1} \mathrm{~h}^{-1} \pm \mathrm{SD}$ ) were (Ec) $356 \pm 59_{i}$ (Ul) 200 \pm 81 ; (An) $148 \pm 35$; ( Hm) $92 \pm 19 ;(\mathrm{Pp}) 35 \pm 5$; (Sv) $29 \pm 14$
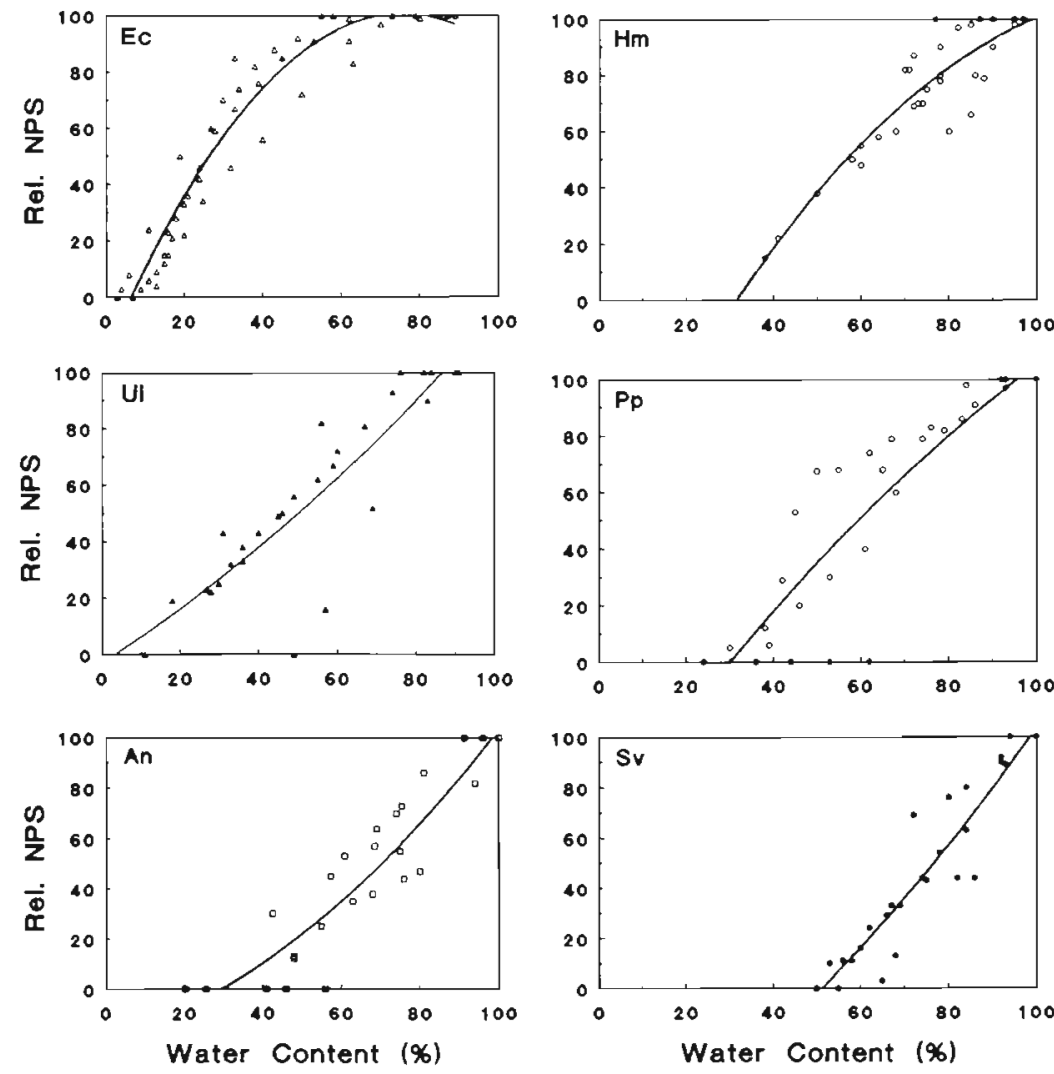

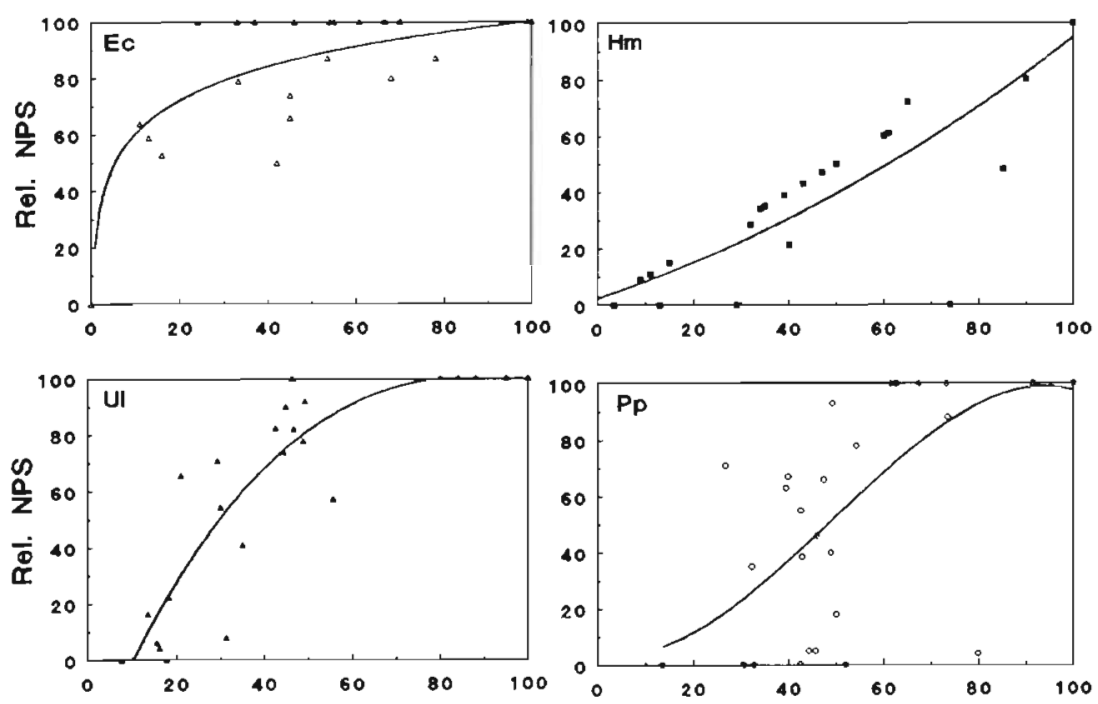

Fig. 5. Enteromorpha compressa (Ec), Ulva lactuca (Ul), Acanthophora najadiformis (An), Hypnea musciformis (Hm), Padina pavonia (Pp), and Sargassum vulgare (Sv). Photosynthetic recovery after desiccation, measured as rates of net photosynthetic $\mathrm{O}_{2}$ evolution (during submersion), as a function of the relative water content to which the thalli were desiccated. Measurements were done on 16 thalli for each species at a temperature of $25^{\circ} \mathrm{C}$ and, during the photosynthetic measurements, an irradiance of 1000 $\mu \mathrm{mol}$ photons $\mathrm{m}^{-2} \mathrm{~s}^{-1}$. Data are expressed relative to maximal rates obtained for each thallus (as measured prior to desiccation). Average maximal rates (in $\mu \mathrm{mol} \mathrm{O}_{2} \mathrm{~g} \mathrm{FW}^{-1} \mathrm{~h}^{-1} \pm \mathrm{SD}$ ) were for (EC*) $110 \pm 36$; (Ul') $195 \pm 45$; (An*) $52 \pm$ 15; $(\mathrm{Hm} \cdot) 90 \pm 14_{i}(\mathrm{Pp})(45 \pm 16)_{i}(\mathrm{~Sv}) 35$ \pm 19 ("after Einav \& Beer 1993)
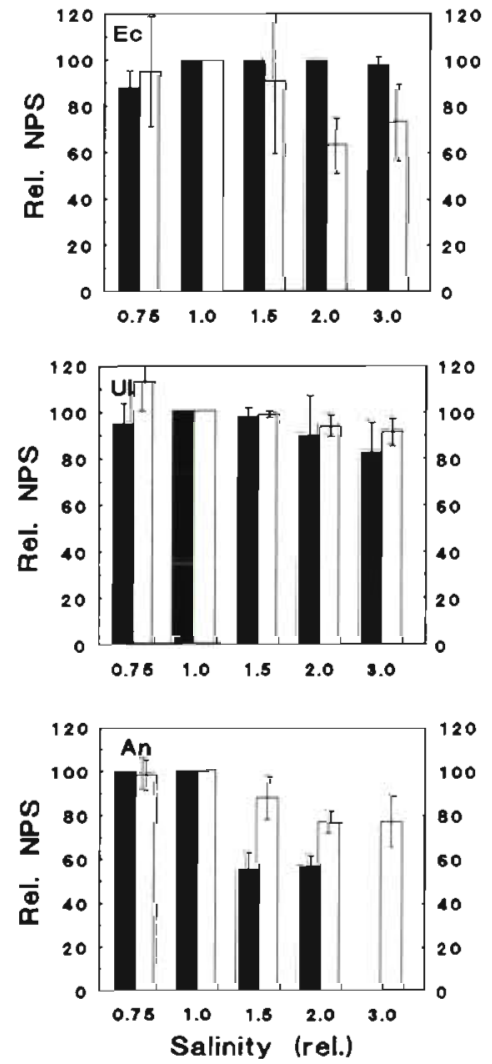
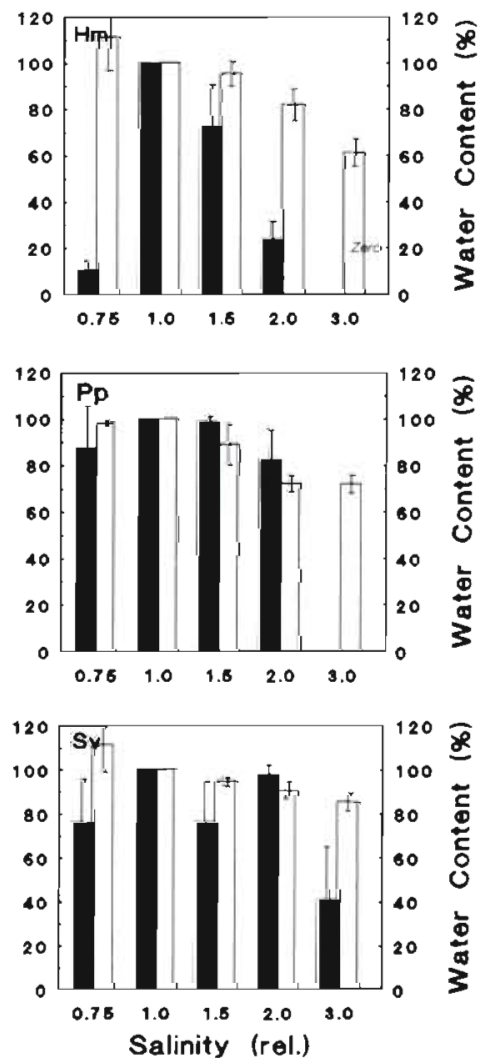

Fig. 6. Enteromorpha compressa (ec), Ulva lactuca (Ul), Acanthophora najadiformis (An), Hypnea musciformis (Hm), Padina pavonia (Pp), and Sargassum vulgare (Sv). Net photosynthetic $\mathrm{O}_{2}$ evolution rates of submerged algae (solid bars) and net water content (open bars) as a function of relative salinity. Measurements were done on 16 thalli of each species at a temperature of $25^{\circ} \mathrm{C}$ and an irradiance of $1000 \mu \mathrm{mol}$ photons $\mathrm{m}^{-2} \mathrm{~s}^{-1}$. Data are expressed relative to maximal rates obtained initially (at 1.0 relative salinity, see 'Materials and methods') 
Fig. 7. Enteromorpha compressa (Ec), Ulva lactuca (U1). Acanthophora najadiformis (An), Hypnea musciformis ( $\mathrm{Hm})$, Padina pavonia (Pp), and Sargassum vulgare (Sv). Net photosynthetic $\mathrm{CO}_{2}$ uptake rates of algae in the air as a function of $\mathrm{CO}_{2}$ concentration. Measurements were done on 6 thalli of each species at a temperature of $25^{\circ} \mathrm{C}$ and an irradiance of $1600 \mu \mathrm{mol}$ photons $\mathrm{m}^{-2} \mathrm{~s}^{-1}$. Data are expressed relative to maximal rates of each thallus
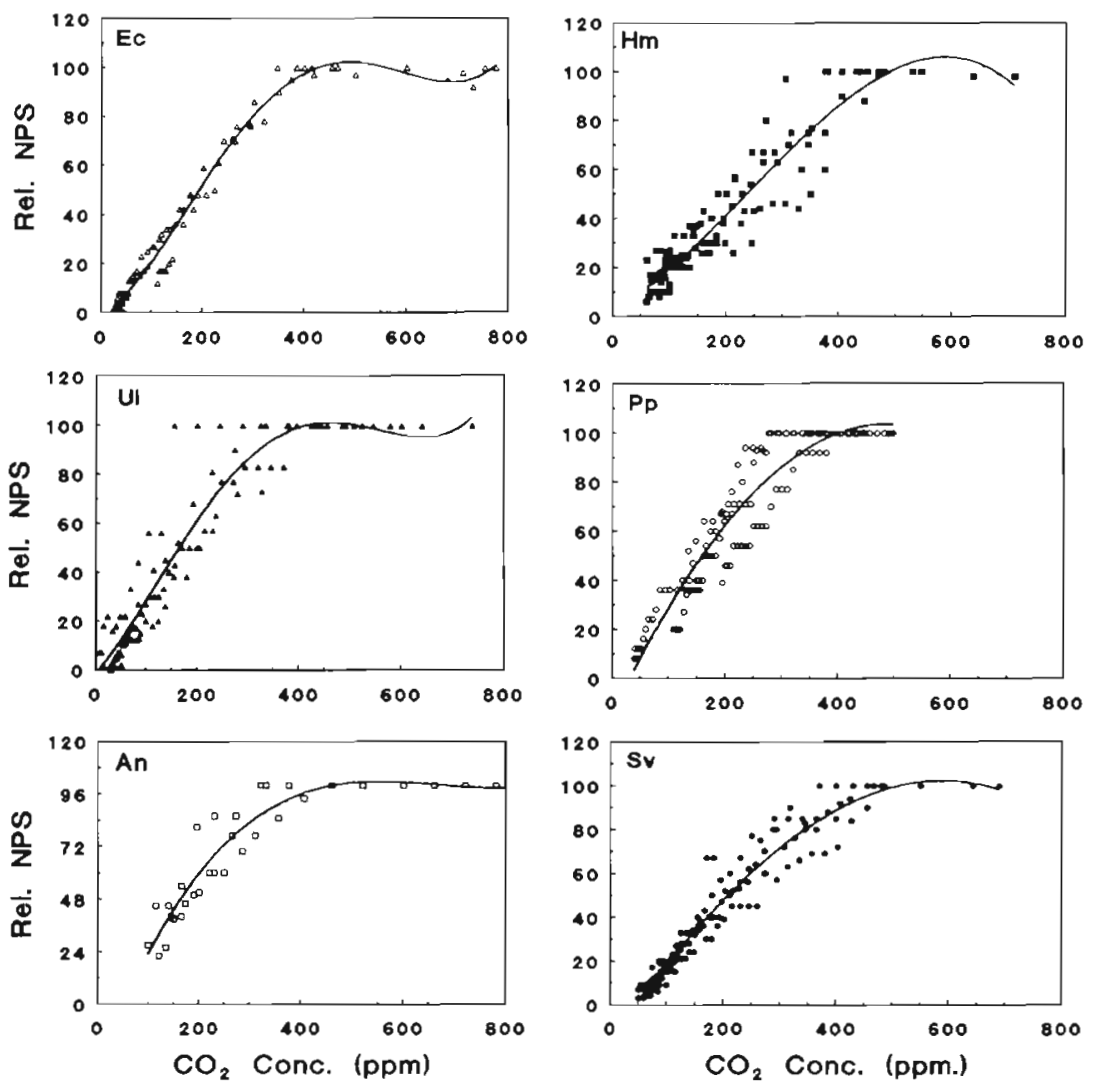

especially, Acanthophora najadiformis photosynthesised at much higher rates in air than in water (Fig. 9).

Differences in photosynthetic rates between air and water (Fig. 9) might depend on the ambient inorganic carbon source. Since the absolute concentrations of $\mathrm{CO}_{2}$ and $\mathrm{HCO}_{3}{ }^{-}$within a closed system vary as a function of $\mathrm{pH}$, various concentrations of the 2 carbon forms were created by injecting buffers into the photosynthetic measuring system during steady-state $\mathrm{O}_{2}$ evolution. The normal inorganic carbon composition at $\mathrm{pH} 8.2\left(12 \mu \mathrm{M} \mathrm{CO} 2\right.$ and $\left.1845 \mu \mathrm{M} \mathrm{HCO}_{3}^{-}\right)$was thus changed to $195 \mu \mathrm{M} \mathrm{CO}_{2}$ and $1980 \mu \mathrm{M} \mathrm{HCO}_{3}{ }^{-}$at $\mathrm{pH} 7.0$ and $1665 \mu \mathrm{M} \mathrm{CO}_{2}$ and $530 \mu \mathrm{M} \mathrm{HCO}_{3}^{-}$at $\mathrm{pH} 5.5$. Fig. 10 shows the photosynthetic performance of the algae at the 3 different $\mathrm{pH}$ values. The results were

Fig. 8. Enteromorpha compressa (Ec), Ulva lactuca (Ul), Acanthophora najadiformis (An). Hypnea musciformis (Hm), Padina pavonia (Pp), and Sargassum vulgare (Sv). (a) Absolute rates $\left( \pm \mathrm{SD}\right.$ ) of net photosynthetic $\mathrm{O}_{2}$ evolution of 4 to 6 thalli of algae when submerged in normal seawater (solid bars) and in seawater with added inorganic carbon (open bars) measured at a temperature of $25^{\circ} \mathrm{C}$ and an irradiance of $1000 \mu \mathrm{mol}$ photons $\mathrm{m}^{-2} \mathrm{~s}^{-1}$ (b) Relative ratios between normal seawater rates and those obtained with the addition of inorganic carbon (Ci)
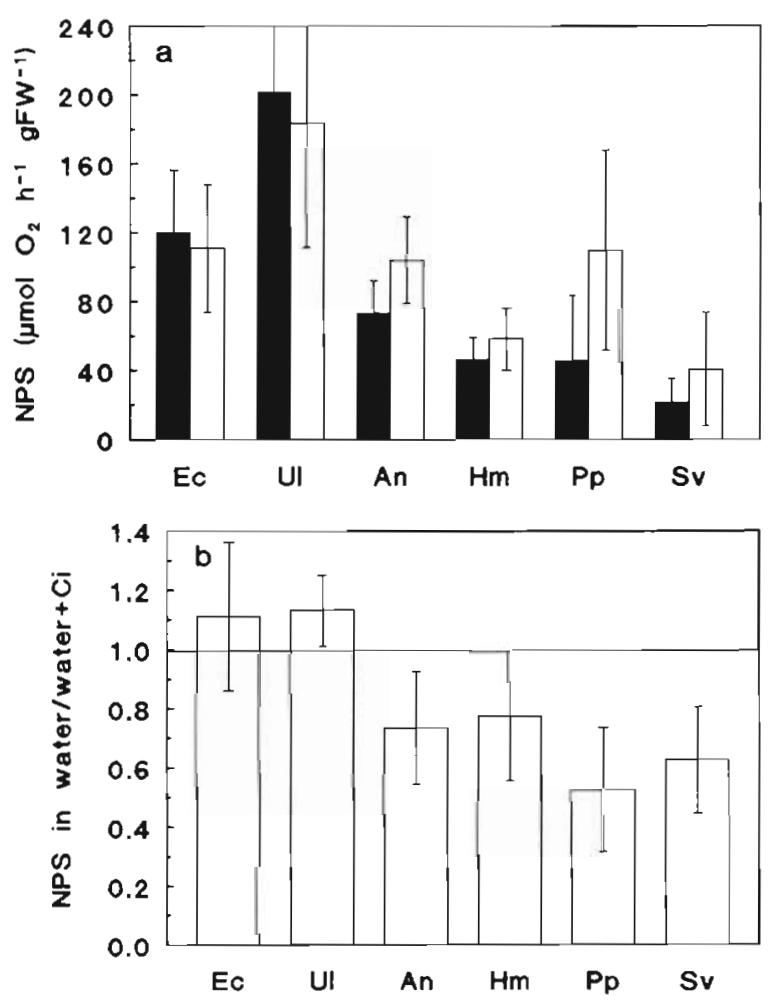

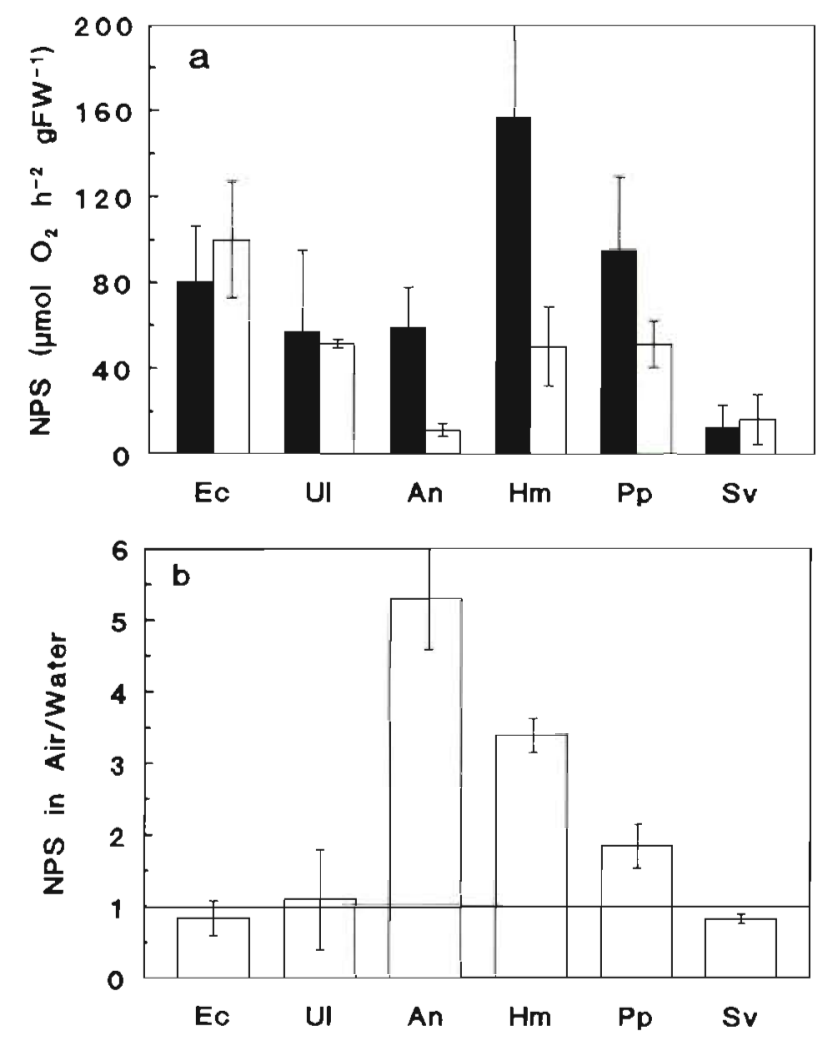

Fig. 9. Enteromorpha compressa (Ec), Ulva lactuca (Ul), Acanthophora najadiformis (An), Hypnea musciformis (Hm), Padina pavonia (Pp), and Sargassum vulgare (Sv). (a) Absolute rates of net photosynthetic $\mathrm{O}_{2}$ evolution of 4 to 6 thalli of emergent (solid bars) and submerged (open bars) algae, measured at a temperature of $25^{\circ} \mathrm{C}$ and an irradiance of $1000 \mu \mathrm{mol}$ photons $\mathrm{m}^{-2} \mathrm{~s}^{-1}$. (b) Relative ratios between emergent and submerged rates

calculated relative to initial photosynthetic rates of each thallus measured in natural seawater (before the buffer addition). Although the buffers used to vary the pH are 'biological' buffers, and thus ideally should not influence metabolism, the possibility of metabolic effects can not be excluded here. This is exemplified at $\mathrm{pH} \mathrm{8.2,} \mathrm{which} \mathrm{is} \mathrm{the} \mathrm{normal} \mathrm{pH}$ of seawater, but which, when maintained with Tris, usually caused lower photosynthetic rates than those found in natural seawater. In addition, the lower $\mathrm{pH}$ per se of the other buffers used could also have affected photosynthetic rates. Enteromorpha compressa and Ulva lactuca show almost the same rates at all $\mathrm{pH}$ values and, therefore (as was also found in other experiments; Fig 8), seemed to saturate their photosynthetic systems by the ambient inorganic carbon content of seawater. Since the inorganic carbon concentration is composed mainly of $\mathrm{HCO}_{3}{ }^{-}$at $\mathrm{pH} 8.2$, it is indicated that these species are good $\mathrm{HCO}_{3}$ - users and, therefore, take no advantage of the relatively higher $\mathrm{CO}_{2}$ concentration

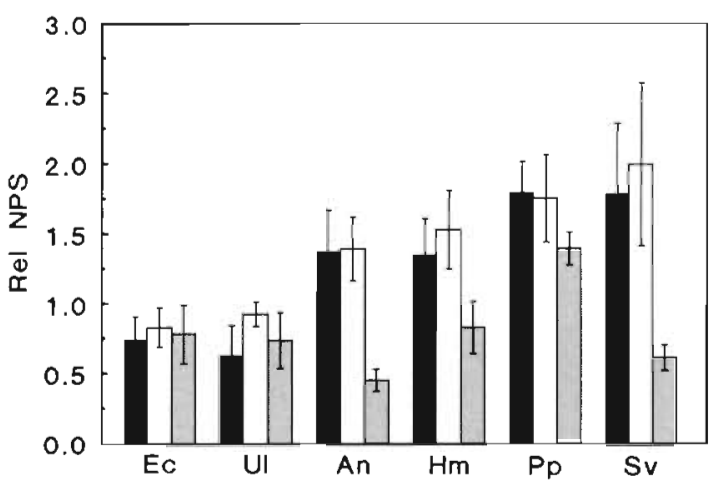

Fig. 10. Enteromorpha compressa (Ec), Ulva lactuca (UI), Acanthophora najadiformis (An), Hypnea musciformis ( $\mathrm{Hm}$ ), Padina pavonia (Pp), and Sargassum vulgare (Sv). Net photosynthetic $\mathrm{O}_{2}$ evolution rates of submerged algae at various $\mathrm{pH}$ values ( $\mathrm{pH}$ 5.5: solid bars; $\mathrm{pH} 7.0$ : open bars; $\mathrm{pH}$ 8.2: shaded bars). Measurements were done on 5 thalli for each species at a temperature of $25^{\circ} \mathrm{C}$ and an irradiance of $1000 \mu \mathrm{mol}$ photons $\mathrm{m}^{-2} \mathrm{~s}^{-1}$ Data are expressed relative to maximal rates obtained for each thallus in normal seawater

at the lower pH values. Acanthophora najadiformis and Hypnea musciformis photosynthesised at higher rates at the lower $\mathrm{pH}$ values, indicating that they are less efficient $\mathrm{HCO}_{3}{ }^{-}$users (and therefore have a higher affinity for $\mathrm{CO}_{2}$ ). This is also supported by the findings that photosynthetic rates in the air, where only $\mathrm{CO}_{2}$ is present, are high (Fig. 9). Padina pavonia and Sargassum vulgare also showed higher rates at lower $\mathrm{pH}$ values, indicating that they also prefer $\mathrm{CO}_{2}$ to $\mathrm{HCO}_{3}{ }^{-}$.

\section{DISCUSSION}

Plants living within the intertidal zone are exposed to extremely varying conditions during the tidal cycle. Such conditions are most harsh for benthic algae in the high intertidal, where factors causing desiccation and/or critical temperatures dictate the upper limit for growth. The ability to compete and grow high up in the zone will thus largely depend on physiological responses to such abiotic factors (cf. Chapman 1965). In the intertidal zone of tropical and subtropical regions such as the Israeli coast, extremely contrasting growth conditions can be found within a very short distance (the mean tidal amplitude in the Mediterranean is only ca $30 \mathrm{~cm}$ ), from complete immersion in seawater to almost complete exposure to an arid atmosphere during low tide. Under these conditions, winds and waves are also of importance in determining the degree of moisture of the thalli. Sometimes easterly winds smooth the sea and this, along with the dryness of such winds, may cause the death of algae growing 
high up on the rocks. On the other hand waves, especially in the summer, are important in wetting the exposed plants.

Tolerance to water loss during emergence and, especially, the degree of photosynthetic recovery upon resubmergence have been viewed as physiological requirements for algae growing high up in the intertidal (e.g. Beer \& Kautsky 1992, Dring \& Brown 1992). This also seems to be the case for the algae studied here (Figs. 4, 5 \& 6). Ulva lactuca and Enteromorpha compressa thus thrive high up in the zone because of their relative tolerance to desiccation (while their ultimate upper limit for growth is determined by conditions of severe desiccation). On the studied shore, only Porphyra linearis features an even higher resistance to desiccation (Lipkin et al. 1993), but other species of the zone do not show such durability and, therefore, do not compete with E. compressa and $U$. lactuca in their niche. The ability of at least $U$. lactuca to withstand high temperature for prolonged time periods (Fig. 4) is likely also an important component of its survival strategy in the upper intertidal. Resistance to low temperatures (Fig. 2) may also allow E. compressa to thrive in the winter months when, indeed, it is the most abundant alga of the shore.

Photosynthetic rates of Enteromorpha compressa and Ulva lactuca are close to carbon-saturation in air (Fig. 7) and are carbon-saturated in seawater (Figs. 8 \& 9). Thus they, like many other algae (Sand-Jensen \& Gordon 1984, Brechignac et al. 1986, Cook et al. 1986 , Beer \& Shragge 1987, Raven et al. 1989, Surif \& Raven 1989, 1990, Madsen \& Maberly 1990, Israel \& Beer 1992), are good $\mathrm{HCO}_{3}{ }^{-}$users (Fig. 10). It has been shown that $U$. lactuca features a $\mathrm{CO}_{2}$-concentrating mechanism (Beer et al. 1990), and it is likely that $\mathrm{HCO}_{3}{ }^{-}$use is the basis for such a system (Drechsler \& Beer 1991). Based on our results, there does not seem to be any physiological limitation that would prevent $U$. lactuca and E. compressa from growing submerged, and biotic factors therefore probably contribute in determining the lower limit of their populations. Usually, when abiotic factors are not very stressful, biotic factors such as grazing and competition become more important (Slocum 1980, Paine \& Levin 1981, Moreno \& Sutherland 1982, Littler \& Littler 1984). Lundberg $(1980,1981)$ found that E. compressa and U. lactuca are preferred by herbivorous fish, which could be a reason why they do not thrive when totally submerged (where the fish could reach them all the time). Many investigators view the upper limit of intertidal algal zonation to be set by abiotic factors while the lower limit is determined by biological ones (Hodgson 1980 , Foster 1982, Cubit 1984, Dring 1994): the attributes of these green algae support this view.

Growing high on intertidal rocks has its benefits, and often large stands of the green algae Ulva lactuca and
Enteromorpha compressa can be found tied to the substrate. However, sometimes this habitat can be too harsh. Wave action is critical for the exposed populations, especially in summer during extremely hot and dry weather caused by southeastern winds known as 'khamsins', which can smooth the sea for several days. During this time, most upper-intertidal populations dry and die. In the wintertime, when the waves are high, plants developing large thalli are detached from the rocks by the strong surf. Recovery of the population after such catastrophes may take months (Einav 1993).

The best correlation between the vertical placement of algae and their physiological response was found for the 2 red algae Acanthophora najadiformis and Hypnea musciformis. These species occupy a very narrow belt of the mid littoral, where they are exposed to air intermittently during the day, but are always made wet again by the waves (Table 1). They cannot grow higher up since they are very sensitive to atmospheric influences such as high temperature (Fig. 3), desiccation (Figs. $4 \& 5$ ) and salinity (Fig. 6), but at the same time they exhibit 3 to 5 times higher photosynthetic rates in air than in water (Fig. 9). These algae perform poorly when totally submerged (as implied by their carbonlimitation in seawater; Fig, 8), probably because they are poor $\mathrm{HCO}_{3}{ }^{-}$users (as indicated by their lower photosynthetic rates during immersion at high than at low pH; Fig. 10). Since, according to Lundberg (1980, 1981), they are not eaten by herbivorous fish, we can thus point to 2 purely physiological responses to abiotic parameters which likely determine both their upper and lower limits of distribution: they benefit from exposure as long as they do not desiccate too much and would suffer from total submergence since photosynthetic rates in seawater are low.

The lower range of the intertidal, and the shallow subtidal, is occupied mostly by Padina pavonia (which has a very wide vertical distribution) and Sargassum vulgare (which is rarely exposed). They are very sensitive to atmospheric influences (Figs. 3, 4, 5, 6 \& 7), which prevent them from growing higher up. P. pavonia photosynthesises faster in air than in water, while $S$. vulgare apparently does not benefit from exposure (Fig. 9). This might be a partial explanation of the wider distribution of $P$. pavonia. Neither species of brown alga is carbon-saturated in seawater (Fig. 8), and they can use more inorganic carbon if provided as $\mathrm{CO}_{2}$ (Fig. 10). Still, they appear in large amounts in the subtidal were they are far from carbon-saturation. The restriction of the brown algae to the lower part of the zone can not be readily explained by the present results.

In summary, it seems that ecophysiological responses enable Enteromorpha compressa and Ulva lactuca to grow high up in the Israeli intertidal zone where competition from other species, which are more sensitive to 
emergent conditions, is virtually absent. The sensitivity of Acanthophora najadiformis and Hypnea musciformis to atmospheric influences, in combination with their preference for atmospheric $\mathrm{CO}_{2}$, dictates their growth in the turbulent mid intertidal. In the lower part of the intertidal zone, it seems that biotic rather than abiotic factors determine the distribution of algae.

Acknowledgements. This work was carried out within the framework of cooperation between the Tel Aviv and Bielefeld Universities and is part of a Ph.D. dissertation by R.E. The corrections and patience of 3 anonymous reviewers are greatly appreciated.

\section{LITERATURE CITED}

Beer S (1994) Mechanisms of inorganic carbon acquisition in marine macroalgae (with special reference to the Chlorophyta). In: Round FE, Chapman DJ (eds) Prog Phycol Res 10:179-207

Beer S, Eshel A (1983a) Photosynthesis of Ulva sp. I. Effects of desiccation when exposed to air. J exp mar Biol Ecol 70 : 91-97

Beer S, Eshel A (1983b) Photosynthesis of Ulva sp. I1. Utilization of $\mathrm{CO}_{2}$ and $\mathrm{HCO}_{3}{ }^{-}$when submerged. $J$ exp mar Biol Ecol 70:99-106

Beer S, Shragge B (1987) Photosynthetic Carbon metabolism in Enteromorpha compressa (Chlorophyta). J Phycol 23: $580-584$

Beer S, Drechler Z, Israel A, Cohen Y (1990) Photosynthesis in Ulva fasciata. $V$. evidence for an inorganic carbon concentrating system, and ribulose-1.5-bisphosphate carboxylase/oxygenase $\mathrm{CO}_{2}$ kinetics. Plant Physiol 94:1542-1546

Beer S, Kautsky L (1992) The recovery of net photosynthesis during rehydration of 3 Fucus species from the Swedish west coast following exposure to air. Botanica mar 35 : $487-491$

Brechignac F, Andre M, Gerbaud A (1986) Preferential photosynthetic uptake of exogenous $\mathrm{HCO}_{3}{ }^{-}$in the marine macroalga Chondrus crispus. Plant Physiol 80:1059-1062

Chapman VJ (1965) The physiological ecology of some New Zealand seaweeds. In: McLachlan JL, Young M (eds) Proc 5 th int Seaweed Symp. Wiley and Sons, New York, p 29-54

Cook CM, Lanaras T, Colman B (1986) Evidence for bicarbonate transport in species of red and brown macrophytic marine algae. $J$ exp Bot $37: 977-984$

Cubit JD (1984) Herbivory and the seasonal abundance of algae on a high intertidal rocky shore. Ecology 65: $1904-1917$

Drechsler Z, Beer S (1991) Utilization of inorganic carbon by Ulva lactuca. Plant Physiol 97:1439-1444

Dring MJ (1994) The biology of marine plants. Cambridge University Press, Cambridge,

Dring MJ, Brown FA (1992) Photosynthesis of intertidal brown algae during and after periods of emersion: a renewed search for physiologcal causes of zonation. Mar Ecol Prog Ser 8:301-308

Einav R (1993) Ecophysiological adaptation strategies of intertidal marine macroalgae in the Mediterranean, Israel. PhD dissertation, Bielefeld University

Einav R, Beer S (1993) Photosynthesis in air and in water of Acanthophora najadiformis growing within a narrow zone of the intertidal. Mar Biol 117:33-138
Foster MS (1982) Factors controlling the intertidal zonation of Iridaea flaccida (Rhodophyta). J Phycol 18:285-294

Hodgson LM (1980) Control of the intertidal distribution of Gastroclonium coulteri in Monterey Bay, California, USA. Mar Biol 57:121-126

Israel A, Beer S (1992) Photosynthetic carbon acquisition in the red alga Gracilaria conferta. Il. Rubisco carboxylase kinetics, carbonic anhydrase and $\mathrm{HCO}_{3}^{-}$uptake. Mar Biol 112:697-700

Johnston $M$ (1991) The acquisition of inorganic carbon by marine macroalgae. Can J Bot 69:1123-1132

Kirst GO (1990) Salinity tolerance of eukaryotic marine algae. Annu Rev Plant Physiol Plant Mol Biol 41:21-53

Lipkin Y, Beer S, Eshel A (1993) The ability of Porphyra linearis (Rhodophyta) to tolerate prolonged periods of desiccation. Botanica mar 36:517-523

Littler MM, Littler DS (1984) Relationships between macroalgal functional form groups and substrata stability in a-subtropical rocky-intertidal system. J exp mar Biol Ecol 74:13-34

Lundberg B (1980) Selectivity of food algae by the herbivorous fish Siganus rivulatus in the marine vegetation at Mikhmorret (the Mediterranean coast of Israel). PhD dissertation, The Hebrew University, Jerusalem

Lundberg B (1981) The algal vegetation at a platform shore at Mikhmoret. In: Xth Int Seaweed Symp. Walter de Gruyter \& Co, Berlin, p 315-320

Madsen T, Maberly S (1990) A comparison of air and water as environments for photosynthesis by the intertidal alga Fucus spiralis (Phaeophyta). J Phycol 26:4-30

Moreno CA, Sutherland JP (1982) Physical and biological processes in a Macrocystis pyrifera community near Valdivia, Chile. Oecologia 55:1-6

Oates BR (1985) Photosynthesis and amelioration of desiccation in the intertidal saccate algae Colpomenia peregrina Mar Biol 89:09-119

Paine RT, Levin SA (1981) Intertidal landscapes: disturbance and the dynamics of pattern. Ecol Monogr 51:145-178

Raven JA, Beardall J, Roberts S (1989) The ecophysiology of inorganic carbon assimilation by Durvillaea potatorum (Durvillaeales Phaeophyta). Phycologia 28:429-437

Reiskind JB, Beer S, Bowes G (1989) Photosynthesis, photorespiration and ecophysiological interactions in marine macroalgae. Aquat Bot 34:131-152

Sand-Jensen K, Gordon DM (1984) Differential ability of marine and freshwater macrophytes to utilize $\mathrm{HCO}_{3}{ }^{-}$and $\mathrm{CO}_{2}$. Mar Biol 80:247-253

Schonbeck MW, Norton TA (1979) An investigation of drought avoidance in intertidal fucoid algae. Botanica mar 22:33-144

Slocum CJ (1980) Differential susceptibility to grazers in two phases of an intertidal alga: advantages of heteromorphic generations. J exp mar Biol Ecol 46:9-110

Smith CM, Satoh K, Fork DC (1986) The effects of osmotic tissue dehydration and air drying on morphology and energy transfer in two species of Porphyra. Plant Physiol 80 $843-847$

Surif MB, Raven JA (1989) Exogenous inorganic carbon sources for photosynthesis in water by members of the Fucales and Laminariales (Phaephyta): ecological and taxonomic implicatons. Oecologia 78:97-105

Surif MB and Raven JA (1990) Photosynthetic gas exchange under emerged conditions in eulittoral and normally submersed members of the Fucales and the Laminariales: interpretation in relation to $\mathrm{C}$ isotope ratio and $\mathrm{N}$ and water use efficiency. Oecologia 82:8-80 